\title{
The Amplification of the Abilities of Social Intelligence of Teachers of Contemporary Secondary School
}

\section{Ампліфікація здібностей соціального інтелекту вчителів сучасної середньої загальноосвітньої школи}

Eduard Ivashkevych

Dr. in Psychology, Professor
Едуард Івашкевич

доктор психологічних наук, професор

E-mail:ivashkevych.e@gmail.com orcid.org/0000-0003-0376-4615

Researcher ID: V-8872-2018

Rivne State University

of the Humanities,

Rivne, Ukraine

12, Stepana Bandery str., Rivne, 33000

Liana Onufriieva

Ph. D. in Psychology, Assistant Professor, Professor of the Department of General and Applied Psychology, Head of the Department of General and Applied Psychology
Рівненський державний гуланітарний університет, м. Рівне, Украӥна вул. Степана Бандери, 12, м. Рівне, 33000

Ліана Онуфрієва кандидат психологічних наук, доцент, професор кафедри, завідувач кафедри загальної та практичної психології

\section{E-mail:kpnu_lab_ps@ukr.net orcid.org/0000-0003-2442-4601 \\ Researcher ID: R-5598-2018}

Kamianets-Podilskyi National

Ivan Ohiienko University, Kamianets-Podilskyi, Ukraine 61, Ohiienka str., Kamianets-

Podilskyi, Khmelnytskyi region, 32300
Кал'янець-Подільський національний університет імені Івана Огієнка, л. Кал'янеиь-Подільський, Україна вул. Огієнка, 61 , м. Кам'янець-Подільський, Хмельницька обл., 32300 
Original manuscript received December 18, 2018

Revised manuscript accepted January 24, 2019

\section{ABSTRACT}

The article states that social intelligence is considered as the ability that has certain peculiarities. Thus, the explication of social intelligence is possible only within the process of the subject-subject activity. It was noted that the amplification of the abilities of social intelligence took place in the process of interpersonal interaction. Taking into account the multidimensional nature of the scope of exploring these abilities, it is obvious that social intellect contains a certain complex of capabilities that are clearly consistent with each other, and they are rather stable for each person. It was determined that the development of this group of abilities was due to the process of socialization of the person, the influence of both internal resources and characterological characteristics of the person, gender differences, etc., and according to the impact of the environment on a person.

The authors of the article believe that the social intelligence of the teacher contains cognitive, empathic and mnemonic aspects. Elements (or scripts, frames, concepts) of the empathic aspect of social intelligence are the content of specific educated perceptions of the images of the reality that can be perceived directly, and all those content arises some images in the memories and the imagination of the person. The specific function of the empathic aspect of social intelligence is that empathic frames, scripts, and concepts give emotional products of the intellectual activity, form a peculiar picture of the world that can be considered as a result of the work of social intelligence, which causes the world to appear to the subject as continue existing in the paradigm of metacognitive field.

The obtained results about the levels of social intelligence of teachers indicate that the level of the development of social intelligence does not depend on the level of qualification of a teacher, that is, on the length of work at school, the age of the respondents, etc. It was proved that the social intelligence of the teacher depended, first of all, on the gender characteristics of the respondents, as well as on the subject area of the professional activities that the teacher was engaged in since he/she finished the university. Consequently, the level of the development of social intelligence of a teacher will depend on the psychological type of his/her personality, and this type, in turn, predetermined the choice of the respondent in one or another sphere of the professional activity (for example, natural sciences or humanities ones, or 
Physics and Math, the profession of the teacher of primary school, etc.). The psychological type of the teacher's personality in a great degree provides so called amplified structure of the teacher's abilities that are the part of his/her social intelligence.

Key words: social intelligence, cognitive aspect, empathic aspect, mnemic aspect, metacognitive sphere, amplification of the abilities of social intelligence.

\section{Вступ}

Узагальнення існуючих у науковій літературі підходів до визначення поняття «соціальний інтелект» дає змогу окреслити психологічний зміст і сутність соціального інтелекту особистості, а також проаналізувати його структуру. Так, соціальний інтелект розглядається як здатність, що має такі особливості:

1) експлікація соціального інтелекту є можливою лише в межах здійснення особистістю суб’єкт-суб’єктної діяльності;

2) ампліфікація здібностей соціального інтелекту відбувається у процесі міжособистісної взаємодії;

3) ураховуючи багатоаспектний характер сфери експлікації цих здібностей, то очевидно, що соціальний інтелект уміщує певний комплекс здатностей, які чітко узгоджені між собою та є доволі сталими у конкретної особистості;

4) становлення цієї групи здібностей зумовлено процесом соціалізації особистості, впливом як внутрішніх ресурсів і характерологічних особливостей індивіда, гендерних відмінностей тощо, так і впливом на людину оточуючого середовища.

У дослідженнях І. В. Ващенко, Л. А. Онуфрієвої (Ващенко \& Онуфрієва, 2018), Ю. М. Ємельянова (Ємельянов, 1991), В. М. Куніциної (Куніцина, 1995), Л. А. Онуфрієвої (Онуфрієва, 2016) та ін. охарактеризовано взаємозв'язок рівнів розвитку соціального інтелекту та комунікативної компетентності особистості, що також, певною мірою, призводить до зближення семантики цих нетотожних понять. 3 урахуванням сучасних психологічних досліджень 
можна стверджувати, що комунікативна компетентність є складним утворенням, яке інтегрує в своєму змісті знання, вміння і навички, комунікативні якості та властивості, комунікативно-рефлексивні й операціонально-діяльнісні характеристики, що у своїй цілісності становлять доволі стійке особистісне новоутворення. Комунікативна компетентність, як правило, описується через зміст запропонованих компонентів:

- мотиваційно-ціннісного компонента, який визначається потребою людини в збагаченні особистісних і професійних контактів, толерантним ставленням до партнера по спілкуванню, що виявляється в таких якостях особистості, як контактність, активність у спілкуванні, вміння вибудовувати довірчі, толерантні, суб'єкт-суб'єктні стосунки з колегами;

- когнітивного компонента, що визначається сформованістю мовної, міжкультурної, соціальної та інших компетентностей, свідчить про уміння виробляти стратегію ефективної міжособистісної взаємодії, уникати конфліктів у спільній діяльності;

- операціонального компонента, який розглядається як показник «культурної зрілості», характеризується наявністю умінь управління власною комунікативною діяльністю, високим рівнем розвитку комунікативно-рефлексивних умінь, що забезпечують розуміння сутності комунікативної ситуації, своїх комунікативних потреб і намірів, опанування комунікативними способами виконання діяльності (Аргайл, Ферн \& Грехем, 1981).

Системне цілісне уявлення щодо структури комунікативної компетентності, виокремлення пї особливостей i функцій стосовно соціального інтелекту (Г. Оллпорт (Оллпорт, 1937), М. Аргайл (Аргайл, Ферн \& Грехем, 1981), М. О. Амінов, М. В. Молоканов (Амінов \& Молоканов, 1992)) дає змогу конкретизувати поняття комунікативної компетентності педагога: комунікативна компетентність є однією зі складових соціальної компетентності, розгляда- 
ється як комплекс властивостей, що фасилітують комунікативний процес, формування таких інтегральних комунікативних властивостей своєї особистості, як психологічна контактність, комунікативна адаптованість і комунікативна прийнятність. Останні ми розглядаємо як детермінанти соціального інтелекту. Отже, комунікативна компетентність є складовою соціальної компетентності, що розглядаються науковцями як підструктури соціального інтелекту педагога. Тому ми вважаємо соціальний інтелект педагога когнітивною основою для реалізації міжособистісного спілкування, оскільки соціальний інтелект постає детермінантою не тільки прогнозування міжособистісної комунікативної взаємодії, а й організації ефективних міжособистісних стосунків, які є невід'ємною складовою спілкування з урахуванням його динамічних характеристик.

Аналіз таких дефініцій, як «соціальний інтелект», «соціальна компетентність» $\mathrm{i}$ «комунікативна компетентність» дав змогу зробити певні висновки. По-перше, соціальний інтелект є особистісним новоутворенням, що вміщує певну, чітко структуровану групу ментальних здібностей, які характеризуються не тільки когнітивними, а й конативними аспектами. По-друге, соціальний інтелект слід розглядати як когнітивну основу соціальної та комунікативної компетентності (які, на думку Дж. Кілстрома та Н. Кентор (Кілстром \& Кентор, 1987), входять до структури соціального інтелекту), що вирізняється особливою специфікою пізнання (при цьому, характерологічними особливостями такого пізнання постають можливість урахування власне особистісного досвіду, а також здійснення комунікації з метою актуалізації такого пізнання). По-третє, специфіка пізнання з ціллю становлення соціального інтелекту полягає в його когнітивно-афективному характері, який є основою для формування ставлення до певного об'єкта пізнавальної діяльності. По-четверте, становлення соціального інтелекту відбувається у процесі соціалізації особистості, тому на структуру соціального інтелекту, рівень 
його розвитку впливають особистісні властивості індивіда (темперамент, характер тощо), чинники навколишнього середовища (на мікро-, мезо- та макросоціальних рівнях), а також імпліцитний вплив на структуру соціального інтелекту здійснює особистісний і професійно значущий досвід. I, нарешті, по-п'яте, динамічний характер соціального інтелекту дає підстави стверджувати про наявність кількісних і якісних відмінностей, зумовлених особливостями становлення цього особистісного утворення.

Численні дослідження, проведені в парадигмі когнітивного підходу, переконливо довели, що інтелектуальна діяльність має місце навіть тоді, коли сама людина внаслідок інтроспективного аналізу не може про них стверджувально висловлюватися. До класу неусвідомлюваних явищ інтелектуальної діяльності слід також включати механізми роботи інтелекту. Вказівка на те, що сам носій свідомості не здатний описати, як ці механізми функціонують, не може свідчити про їхню відсутність.

Ми вважаємо, що соціальний інтелект педагога вміщує когнітивний, елпатійний і мнемічний аспекти. У попередньому викладі теоретичного матеріалу більшу увагу було приділено мнемічному аспекту соціального інтелекту, тоді як емпатійний аспект, на нашу думку, є не менш важливим. Елементи (або скрипти, фрейми, концепти) емпатійного аспекту соціального інтелекту складають зміст конкретних усвідомлених педагогом образів реальності, які можуть бути такими, що сприймаються безпосередньо, так і такими, що виникають у спогадах і уяві особистості. Специфічна функція емпатійного аспекту соціального інтелекту полягає в тому, що емпатійні фрейми, скрипти, концепти наділяють емоційністю продукти інтелектуальної діяльності, своєрідну картину світу, що складається у суб'єкта в результаті роботи соціального інтелекту, внаслідок чого світ постає для суб'єкта як існуючий у метакогнітивній сфері. Саме тому, на нашу думку, немає сенсу говорити про існування емоційного інтелекту, адже той смисл, 
який вкладається в це поняття багатьма дослідниками, зафіксований саме в емпатійному аспекті соціального інтелекту. Хоча емпатійний аспект соціального інтелекту не усвідомлюється педагогом, саме він, на нашу думку, забезпечує усвідомлення емоційно-експресивної та емпатійної сторін об’єктів і суб’єктів у міжособистісній взаємодії.

Спираючись на теорію О. М. Леонтьєва (Леонтьєв, 1981), ми вважатимемо, що емотивні образи людини наділені такою якістю, як означеність, i найважливішими елементами, що утворюють людську свідомість, а, отже, й інтелект, є значення. Останні, на нашу думку, входять до когнітивного аспекту соціального інтелекту. Проте будьякий інтелект, у тому числі соціальний, не може бути редукований до певного аспекту, який його утворює, в тому числі - й до аспекту значень. Отже, соціальний інтелект не може бути зведений до функціонування засвоєних педагогом соціально, культурно тощо зумовлених значень, які, розгортаючись, управляють інтелектуальною діяльністю людини.

Ми розглядатимемо соціальний інтелект як окреме, досить важливе новоутворення особистості. Соціальний інтелект педагога не можна розглядати лише як здатність людини правильно розуміти свою поведінку i поведінку інших людей у суспільстві. Для нас прийнятною є точка зору В. М. Куніциної (Куніцина, 1995), яка вважає соціальний інтелект багатовимірною структурою, глобальною здатністю, що виникає на основі інтелектуальних, особистісних, комунікативних і поведінкових рис, які включатимуть достатній рівень енергетичної забезпеченості функціонування процесів саморегуляції. Також, ураховуючи описані нами психологічні особливості професійної діяльності педагога, ми дотримуємося позицій Ю. М. Ємельянова (Смельянов, 1991), В. М. Куніциної (Куніцина, 1995), А. Л. Южанінової (Южанінова, 1984), у яких зазначається, що соціальний інтелект уміщує певні компетентності 
(зокрема, комунікативну), які, в свою чергу, забезпечують формування соціальної та професійної компетентностей особистості.

Отже, ми вважатимемо, що соиіальний інтелект є психічним утворенням особистості, багатовимірною, складною когнітивною структурою, що вміщує в собі комунікативну та прогностичну компетентності, когнітивну компетентність тощо. До складу когнітивної компетентності відносимо здібності, які традиційно визначаються в структурі соціального інтелекту та діагностуються відомими тестами, зокрема, методикою Дж. Гілфорда - М. О’Саллівена (Гілфорд \& O’Саллівен): здібність розуміти та передбачати наслідки поведінки людей; здібність до логічного узагальнення важливих ознак і різноманітних невербальних реакцій людини; здібність розуміти зміни значення подібних вербальних реакцій людини залежно від контексту соціальної ситуації, що їх викликала; здібність розуміти логіку розвитку ситуації міжособистісної взаємодії, значення поведінки різних людей у цих ситуаціях, а також емпатію, інтелектуальну й особистісну рефлексію. При цьому, з одного боку, соціальний інтелект постає як певні знання, вміння та навички (або когніції), які використовує педагог як у повсякденному житті, так і під час виконання професійної діяльності; з іншої сторони, соціальний інтелект розглядається нами як здатність до реалізації педагогом прийнятих рішень (або здатність до створення, експлікації й трансформації метакогніцій). Соціальний інтелект ми розглядаємо як здатність до виконання раціональних, мисленнєвих операцій, об’єктом яких постають процеси міжособистісної взаємодії.

До структури соціального інтелекту (рис. 1) було віднесено комунікативну та прогностичну компетентності, які ми розглядаємо як складну, інтегративну систему комунікативних і прогностичних умінь і навичок педагогічної взаємодії, сценаріїв поведінки тощо, котрі дають змогу педагогу швидко й адекватно адаптуватися, приймати до- 
цільні й адекватні рішення, враховуючи зовнішні та внутрішні психосоціальні чинники.

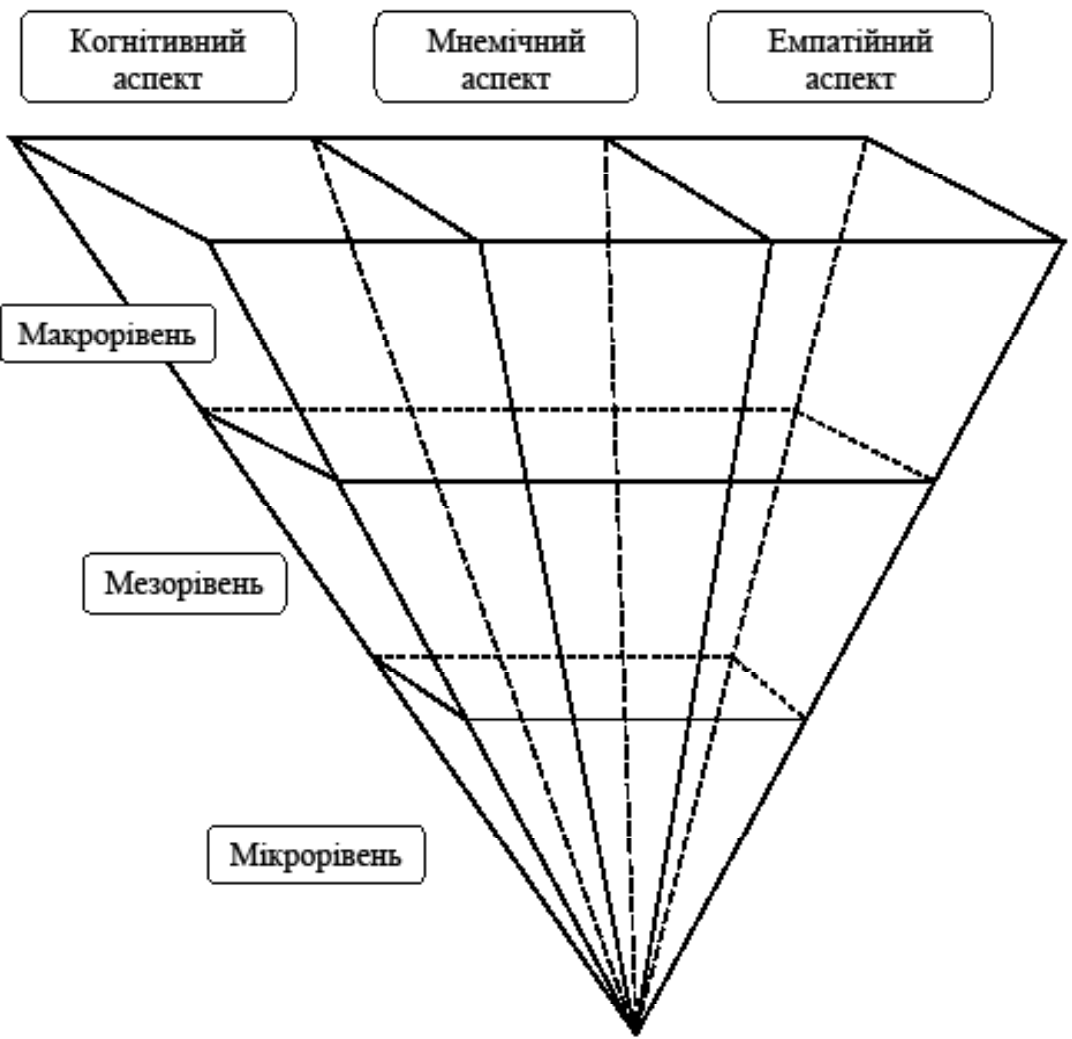

○ Макрорівень: механізми антиципації, децентрації, інтелектуальної ініціації, прийняття рішень, планування, контролю, самоконтролю, рефлексії;

○ мезорівень: прогностична компетентність, емпатія;

○ мікрорівень: когнітивна компетентність, комунікативна компетентність.

Puc. 1. Структура соціального інтелекту педагога

Рефлексія як процес синтезує всю систему інтегральних процесів і сама по собі виникає в такому синтезі. Ti властивості педагога, які, як правило, відрефлексовують- 
ся за допомогою аналізу виконаних дій, постають властивостями інтегральних процесів, забезпечують функціонування рефлексії: цілеспрямованість, можливість ідеального передбачення результатів поведінки (антиципація), свобода вибору (прийняття рішення), аналіз і тлумачення поведінки чи діяльності (її планування та прогнозування), здійснення контролю і самоконтролю виконаних дій тощо. Наявність процесів, що забезпечують здатність особистості відрефлексовувати діяльність, зумовлює феноменологію соціального інтелекту як такого, дозволяє розкрити особливості рефлексії не тільки як процесу, а й рефлексії як стану, що забезпечує функціонування соціального інтелекту особистості.

Мета статті - провести емпіричне дослідження рівня розвитку соціального інтелекту вчителів загальноосвітніх середніх шкіл, описати результати такого дослідження та зробити висновки щодо ампліфікації здібностей соціального інтелекту педагога.

\section{Завдання статті}

1. Розподілити вчителів шкіл за групами залежно від категорії, яку вони мають, типу дисципліни, яку читає цей учитель (до якого циклу навчальних дисциплін належить даний предмет), стажу роботи тощо.

2. Дослідити залежність соціального інтелекту педагога від психологічного типу особистості та гендерних особливостей суб'єкта.

3. Проаналізувати ступінь розвитку здібностей, що входять до структури соціального інтелекту педагога.

\section{Методи та методики дослідження}

На даному етапі проведення емпіричного дослідження взяли участь 395 учителів загальноосвітніх середніх шкіл різних регіонів України та 8 директорів шкіл. На початку дослідження ми припустили, що рівень розвитку соціального інтелекту вчителя загальноосвітньої середньої школи 
залежатиме від категорії, яку він має, типу дисципліни, яку читає цей учитель (до якого циклу навчальних дисциплін належить даний предмет), тобто, від психологічного типу особистості та Іендерних особливостей суб’єкта, тощо. Для зручності опису результатів досліджень (отже, опису тих результатів, які мають або не мають статистично значущу різницю у представників різних груп) усіх респондентів було розподілено за великими та малими експериментальними групами. Так, коли результати респондентів у межах однієї великої експериментальної групи мали статистично значущу різницю, вони були описані виокремлено, з огляду на їх формування в малих групах; у випадку, якщо такої різниці не було, результати всіх респондентів були описані в парадигмі однієї великої, спеціально сформованої для цієї мети групи. Так, усі 403 респонденти були розподілені за такими групами:

1) група $S$ - 103 педагоги III та II категорій (стаж роботи - від 5 до 10 років, вік - до 30 років); із них: 56 учителів ЗОШ № 5 і № 15 м. Рівного, 23 вчителі Шпанівської й Олександрійської загальноосвітніх шкіл Рівненського району, 24 вчителі ЗОШ № 45 і № 96 м. Одеси. У свою чергу, всі вчителі цієї групи були розподілені за підгрупами, залежно від дисципліни, яку вони читають:

- група S1 - 34 вчителі початкових класів (із них -4 чоловіка та 30 жінок);

- група S2 - 35 учителів середньої та старшої ланки навчання природничо-гуманітарного циклу (з них - 17 чоловіків і 18 жінок);

- група S3 - 34 вчителі середньої та старшої ланки навчання фізико-математичного циклу (з них - 17 чоловіків і 17 жінок);

2) група $\mathrm{N}$ - 108 педагогів I категорії (стаж роботи - від 10 до 15 років, вік - від 30 до 35 років), із них -47 учителів ЗОШ № 5 і № 15 м. Рівного, 30 учителів Шпанівської й Олександрійської загальноосвітніх шкіл Рівненського ра- 
йону, 31 учитель ЗОШ № 45 і № 96 м. Одеси. Учителі групи $\mathrm{N}$ були розподілені за мікрогрупами:

- група N1 - 39 учителів початкових класів (усі жінки);

- група N2 - 37 учителів середньої та старшої ланки навчання природничо-гуманітарного циклу (з них - 17 чоловіків і 20 жінок);

- група N3 - 32 вчителі середньої та старшої ланки навчання фізико-математичного циклу (з них - 16 чоловіків і 16 жінок);

3) група M - 110 педагогів вищої категорії (стаж роботи - від 15 та більше років, вік - від 35 років); із них - 55 учителів ЗОШ № 5 і № 15 м. Рівного, 22 вчителі Шпанівської й Олександрійської загальноосвітніх шкіл Рівненського району, 33 вчителі ЗОШ № 45 і № 96 м. Одеси. Учителі групи М були розподілені за мікрогрупами:

- група M1 - 26 учителів початкових класів (усі жінки);

- група М2 - 42 вчителі середньої та старшої ланки навчання фізико-математичного циклу (з них - 22 чоловіка та 20 жінок);

4) група $\mathrm{P}-74$ вчителі-методисти та 8 директорів ЗОШ (стаж роботи - від 35 років, вік - від 40 років), із них - 32 вчителі ЗОШ № 5 і № 15 м. Рівного, 13 учителів Шпанівської й Олександрійської загальноосвітніх шкіл Рівненського району, 29 учителів ЗОШ № 45 і № 96 м. Одеси. До цієї групи також увійшли 8 директорів ЗОШ (крім директорів зазначених шкіл, до груп увійшли директори Здолбунівських шкіл № 5 і 7 Рівненського району). Вчителів групи Р було розподілено за мікрогрупами:

- група P1 - 13 учителів початкових класів (усі жінки);

- група Р2 - 30 учителів середньої та старшої ланки навчання природничо-гуманітарного циклу (з них - 12 чоловіків і 18 жінок);

- група Р3 - 31 учитель середньої та старшої ланки навчання фізико-математичного циклу (з них - 15 чоловіків і 16 жінок); 
- група P4 - 8 директорів ЗОШ (із них - 4 чоловіка та 4 жінки).

Розподіл груп і мікрогруп відбувався за допомогою методу рандомізації (технологія парного дизайну), що дало нам змогу вирівняти кількість чоловіків і жінок у кожній мікрогрупі (виняток становлять лише мікрогрупи, до яких увійшли вчителі початкових класів, адже чоловіків серед цієї категорії педагогів було практично неможливо знайти).

Для діагностики рівня розвитку соиіального інтелекmy нами застосовувалась «Методика дослідження соціального інтелекту» Дж. Гілфорда та М. О’Саллівена, адаптована О. С. Михайловою (Гілфорд \& О’Саллівен).

\section{Результати та дискусії}

Опишемо особливості показників соціального інтелекту вчителів, виявлені на етапі проведення емпіричного дослідження.

За субтестом № 3 «Вербальна експресія», який визначає здатність до розуміння зміни значення подібних вербальних реакцій людей залежно від контексту ситуації, показники жінок усіх груп були дещо вищими, ніж у чоловіків. Отже, за високим рівнем «Вербальної експресії» в групі S2 діагностовано $34,25 \%$ чоловіків і 40,96\% жінок, у групі N2 - 30,95\% чоловіків і 41,16\% жінок, у групі M2 $33,12 \%$ чоловіків і 42,68\% жінок, у групі Р2 - 33,44\% чоловіків і 45,04\% жінок. Різниця цих результатів значуща на рівні достовірності р $<0,05$. Також досить велика кількість респондентів цих груп має середній рівень розвитку соціального інтелекту, виходячи з відповідей субтесту «Вербальна «експресія»: 38,64\% чоловіків і $33,88 \%$ жінок - у групі S2; 39,65\% чоловіків і $34,90 \%$ жінок - у групі N2; 41,59\% чоловіків і 37,28\% жінок - у групі M2; 45,70\% чоловіків і 35,95\% жінок - у групі Р2. Різниця в результатах за середнім рівнем $є$ незначущою у вчителів природничо-гуманітарного циклу, крім групи Р2, де різниця в показниках середнього рівня вербальної експресії між 
чоловіками та жінками є значущою на рівні достовірності $\mathrm{p}<0,01$. Досить велика кількість респондентів усіх груп (до $30 \%$ ) має низький рівень результатів за цим субтестом, що, по-перше, знижуватиме загалом композитну оцінку соціального інтелекту вчителів середньої та старшої ланки навчання природничо-гуманітарного циклу, по-друге, свідчить про більш низький рівень соціального інтелекту цих педагогів порівняно з вчителями початкових класів, які, як правило, мали вищий середнього та високий рівень розвитку соціального інтелекту.

Загалом, отримані дані свідчать про те, що жінки (вчителі природничо-гуманітарного циклу) мають більшу чутливість до характеру та різних проявів людських взаємостосунків і здатні виявляти неабияку рольову гнучкість щодо ситуації, яка виникає. Це, можливо, пояснюється тим, що виховання в парадигмі «любові» (захоплення) до природничо-гуманітарних дисциплін сприяе розвитку в жінок стилю, спрямованого на емоційну чутливість, комунікативну сумісність. У чоловіків, навпаки, заохочується розвиток здатності приховувати та пригнічувати свої почуття, тобто, заохочується емоційна стриманість, змагальність, активність, здатність до контролю ситуації.

Субтест «Історії із завершенням» діагностує рівень розвитку здібності до прогнозування розвитку соціальної ситуації залежно від зовнішніх обставин. Простежується незначна тенденція до більш високих показників соціального інтелекту в жінок, проте відчутних відмінностей у показниках соціального інтелекту чоловіків і жінок за високим, середнім і низьким рівнями не встановлено. Можна зазначити, що досліджувані однаково добре виконали завдання цього тесту, показники високого рівня розвитку соціального інтелекту виявлено у $65,14 \%$ чоловіків і $63,17 \%$ жінок групи S2; у 62,49\% чоловіків і $64,02 \%$ жінок групи N2; у 61,25\% чоловіків і 60,58\% жінок групи M2; у 65,11\% чоловіків і 60,34\% жінок групи Р2. Також 
не виявлено статистично значущої різниці в результатах чоловіків і жінок за середнім і низьким рівнями розвитку соціального інтелекту за I субтестом «Історії із завершенням» (результати за цими рівнями не перевищують 20\% як у чоловіків, так і у жінок), що свідчить про філологічну підготовку вчителів природничо-гуманітарного циклу, адже респонденти з високим рівнем розвитку соціального інтелекту за цим субтестом здатні видобувати максимум інформації про поведінку людей, розуміти мову невербального спілкування, висловлювати швидкі та точні судження про людей, успішно прогнозувати їхні реакції в заданих умовах, виявляти далекозорість у стосунках з іншими, що сприяє їх успішній соціальній адаптації.

Люди з високим рівнем розвитку соціального інтелекту, як правило, бувають успішними комунікаторами. Їм притаманні контактність, відкритість, тактовність, доброзичливість і сердечність. Високий рівень соціального інтелекту пов'язаний з інтересом до соціальних проблем, наявністю потреби впливати на інших і часто поєднується 3 високим рівнем розвитку організаторських здібностей.

Усі перераховані особистісні якості характеризують осіб гуманітарних професій. Це, на нашу думку, значною мірою пояснює отримані високі результати як у жінок, так і у чоловіків за субтестом «Історії із завершенням» у вчителів середньої та старшої ланки навчання природничо-гуманітарного циклу.

За субтестом «Групи експресії», який вимірює чинник пізнання класів поведінки, а саме здібність до логічного узагальнення та виокремлення загальних істотних ознак у різних невербальних реакціях, учителі дисциплін природничо-гуманітарного циклу отримали посередні результати. При цьому, за високим рівнем розвитку соціального інтелекту діагностується статистично значуща різниця в результатах чоловіків і жінок на рівні достовірності p $<0,01$. Так, жінки краще, ніж чоловіки, здатні правильно оцінювати стани, почуття та наміри людей за їх невербальними 
проявами: мімікою, позами та жестами. Високі показники цього субтесту характерні 30,09\% чоловіків і $41,92 \%$ жінок групи S2; 29,92\% чоловіків і 42,16\% жінок групи N2; $31,06 \%$ чоловіків і $42,18 \%$ жінок групи M2; $31,48 \%$ чоловіків і 42,14\% жінок групи Р2.

За субтестом № 2 «Групи експресії» результати середнього рівня розвитку соціального інтелекту діагностовано у $41,75 \%$ чоловіків і $32,74 \%$ жінок групи $\mathrm{S} 2$; у 47,34\% чоловіків і $37,80 \%$ жінок групи N2; у 48,60\% чоловіків i $38,24 \%$ жінок групи М2; у 41,36\% чоловіків і $32,84 \%$ жінок групи Р2. Різниця в результатах між чоловіками та жінками за середнім рівнем є також статистично значущою за t-критерієм Стьюдента на рівні достовірності $\mathrm{p}<0,01$. Учителі, які мають показники середнього та низького рівня, більшою мірою в процесі спілкування орієнтуються на вербальний зміст повідомлень і можуть помилятись у розумінні смислу слів співрозмовника, оскільки не враховують (або враховують неправильно) супутні їм невербальні реакції. Низький рівень розвитку соціального інтелекту вчителів природничо-гуманітарного циклу діагностовано у 28,16\% чоловіків і $25,34 \%$ жінок групи $\mathrm{S} 2$, у $22,74 \%$ чоловіків і 20,04\% жінок групи N2, у 20,34\% чоловіків і 19,58\% жінок групи М2, у 27,16\% чоловіків і $25,02 \%$ жінок групи Р2. Різниця в результатах між чоловіками та жінками за низьким рівнем субтесту № 2 «Групи експресії» є незначущою за t-критерієм Стьюдента на рівнях достовірності $\mathrm{p}<0,01$ i $\mathrm{p}<0,05$.

За субтестом «Історія з доповненням», який вимірює здібність до розпізнавання структури міжособистісних ситуацій у динаміці, простежується тенденція до більш високих показників у чоловіків. Так, високий рівень розвитку соціального інтелекту за цим субтестом діагностовано у $42,57 \%$ чоловіків і $30,94 \%$ жінок групи S2, у $42,36 \%$ чоловіків і 29,28\% жінок групи N2, у 44,68\% чоловіків і $32,19 \%$ жінок групи М2, у 43,01\% чоловіків і $31,24 \%$ жінок групи Р2. Різниця в результатах між чо- 
ловіками та жінками у респондентів усіх груп є значущою за t-критерієм Стьюдента на рівні достовірності p $<0,01$. Респондентів із середнім рівнем розвитку соціального інтелекту, навпаки, дещо більше серед учителів дисциплін природничо-гуманітарного циклу жіночої статі. Так, у групі S2 чоловіків із середнім рівнем розвитку соціального інтелекту за субтестом № 4 «Історії з доповненням» діагностовано 44,24\%, жінок - 49,05\%, у групі N2 - 38,63\% чоловіків і 48,25\% жінок, у групі M2 - 38,31\% чоловіків і 42,65\% жінок, у групі Р2 - 38,89\% чоловіків і 47,68\% жінок. Проте різниця в результатах між чоловіками та жінками за середнім рівнем розвитку соціального інтелекту є значущою за t-критерієм Стьюдента на рівні достовірності $\mathrm{p}<0,01$ лише в групах N2 та P2.

Такий субтест викликав певні складнощі для 13,19\% чоловіків і 20,01\% жінок групи S2, 19,01\% чоловіків i $22,47 \%$ жінок групи N2, 17,01\% чоловіків і $25,16 \%$ жінок групи М2, 18,10\% чоловіків і 21,08\% жінок групи Р2 (ці респонденти вирізняються низьким рівнем розвитку соціального інтелекту), а це свідчить про те, що ці педагоги мають труднощі в аналізі ситуацій міжособистісної взаємодії i, внаслідок цього, характеризуються низьким рівнем адаптивності до різного роду взаємостосунків між людьми (сімейних, ділових, дружніх тощо).

Середні та високі значення показників соціального інтелекту за субтестом «Історія з доповненням» свідчать про те, що досліджувані педагоги добре вміють орієнтуватись у невербальних реакціях людини, а також у нормах і правилах, які регулюють поведінку людей у суспільстві. Шляхом логічних умовиводів вони можуть добудувати невідомі або недостатні ланки в ланцюзі міжособистісної взаємодії, передбачити, як саме людина поводитиме себе у майбутньому. За композитною оцінкою соціального інтелекту середня оцінка жінок дещо вища, ніж оцінка чоловіків, проте, якщо порівнювати цю оцінку з оцінкою соціального 
інтелекту вчителів початкових класів, то вона значно нижча і у чоловіків, і у жінок дисциплін природничо-гуманітарного циклу.

\section{Висновки}

Результати за рівнями сформованості соціального інтелекту вчителів загальноосвітніх середніх шкіл свідчать про те, що від рівня кваліфікації вчителя, тобто від стажу роботи у школі, від віку респондента тощо рівень розвитку соціального інтелекту не залежить. Соціальний інтелект учителя залежить, передусім, від гендерних особливостей респондентів, а також від предметної сфери професійної діяльності, якою педагог займається з моменту закінчення закладу вищої освіти. Тому ми передбачили, що рівень розвитку соціального інтелекту вчителя залежатиме від психологічного типу його особистості, а цей тип, у свою чергу, зумовив обрання респондентом тієї чи іншої сфери професійної діяльності (тобто, природничо-гуманітарної чи фізико-математичної, обрання професії вчителя початкових класів тощо). Саме психологічний тип особистості вчителя, на нашу думку, великою мірою й забезпечує ампліфіковану структуру здібностей педагога, які входять до його соціального інтелекту.

\section{Література}

Аминов Н. А., Молоканов М. В. О компонентах специальных способностей будущих школьных психологов. Психологический журнал. 1992. № 5. С. 13-28.

Ващенко І. В., Онуфрієва Л. А. Сутнісні характеристики та структурні компоненти емоційної зрілості працівників комерційних банків. Psychological Journal. 2018. № 5 (15). P. 224-236. DOI https://doi. org/10.31108/1.2018.5.15.

Гилфорд Дж., О’Салливен М. Тест «Социальный интеллект» (в адаптации Е. С. Михайловой) [Электронный ресурс]. Режим доступа : lib.chdu.edu.ua/pdf/posibnuku/160/41.pdf.

Емельянов Ю. Н. Теория формирования и практика совершенствования коммуникативной компетентности : автореф. дис. ... д-ра психол. наук : 19.00.07. Ленинград, 1991. 36 с. 
Куницына В. Н. Социальная компетентность и социальный интеллект: структура, функции, взаимоотношение. Санкт-Петербург : СПбТУ, 1995. № 2. С. 48-59.

Леонтьев А. Н. Проблемы развития психики. Москва : Изд-во МГУ, $1981.584 \mathrm{c}$.

Южанинова А. Л. К проблеме диагностики социального интеллекта личности. Проблель оценивания в психологии. Саратов, 1984. C. 84-87.

Allport, G. W. (1937). Personality: A Psychological Interpretation. New York, $516 \mathrm{p}$.

Argyle, M., Furnham A., \& Graham, J. (1981). Social situations. London : Cambrige University Press. 133 p.

Cantor, N. G., \& Kihlstrom, J. F. (1987). Personality and social intelligence. New York : Prentice-Hall, Inc. Englewood Cliffs, New Jersey. 420 p.

Onufriieva, L. A. (2016). Emotional intelligence in the future socionomic specialists' professional psychological training. Science and Education a New Dimension. Pedagogy and Psychology, IV (47), Issue 101, 34-37. Budapest.

\section{References}

Aminov, N. A., \& Molokanov, M. V. (1992). O komponentah special'nyh sposobnostej budushchih shkol'nyh psihologov [About the components of special abilities of future school psychologists]. Psyhologicheskij zhurnal - Psychological Journal, 5, 13-28 [in Russian].

Vashchenko, I. V., \& Onufriieva, L. A. (2018). Sutnisni kharakterystyky ta strukturni komponenty emotsiinoi zrilosti pratsivnykiv komertsiinykh bankiv [Essential characteristics and structural components of the commercial banks employees' emotional maturity]. Psychological Journal, 5 (15), 224-236. DOI https://doi.org/10.31108/ 1.2018.5.15.

Guilford, J., \& O'Sulliven, M. Test «Social'nyj intellekt» ( $v$ adaptacii E.S. Mihajlovoj) [The test "Social intelligence» (in adaptation done by E.S. Mikhailova)]. Retrieved from lib.chdu.edu.ua/pdf/posibnu$\mathrm{ku} / 160 / 41 . p d f$ [in Russian].

Jemeljanov, Ju. N. (1991). Teorija formirovanija i praktika sovershenstvovanija kommunikativnoj kompetentnosti [The theory of the development and the practice of improving communicative competence]. Extended abstract of Doctor's thesis. Leningrad [in Russian].

Kunicyna, V. N. (1995). Social'naja kompetentnost' i social'nyj intellekt: struktura, funkcii, vzaimootnoshenie [Social competence and social intelligence: structure, functions, relationships ]. Sankt-Peterburg : SPbTU, № 2, 48-59 [in Russian].

Leontyev, A. N. (1981). Problemy razvitiya psihiki [Problems of the development of the psyche]. Moskva : Izd-vo MGU [in Russian]. 
Yuzhaninova, A. L. (1984). K probleme diagnostiki social'nogo intellekta lichnosti [To the problem of the diagnostics of social intelligence of the personality]. Problemy ocenivanija $v$ psihologii-Problems of evaluation in psychology. Saratov, p. 84-87 [in Russian].

Allport, G. W. (1937). Personality: A Psychological Interpretation. New York, $516 \mathrm{p}$.

Argyle, M., Furnham A., \& Graham, J. (1981). Social situations. London : Cambrige University Press. 133 p.

Cantor, N. G., \& Kihlstrom, J. F. (1987). Personality and social intelligence. New York : Prentice-Hall, Inc. Englewood Cliffs, New Jersey. 420 p.

Onufriieva, L. A. (2016). Emotional intelligence in the future socionomic specialists' professional psychological training. Science and Education a New Dimension. Pedagogy and Psychology, IV (47), Issue 101, 34-37. Budapest.

\section{АНОТАЦІЯ}

У статті зазначено, що соціальний інтелект розглядається як здатність, що має певні особливості. Так, експлікація соціального інтелекту є можливою лише в межах здійснення особистістю суб'єкт-суб'єктної діяльності. Зазначено, що ампліфікація здібностей соціального інтелекту відбувається у процесі міжособистісної взаємодії. Ураховуючи багатоаспектний характер сфери експлікації цих здібностей, є очевидним те, що соціальний інтелект умішує певний комплекс здатностей, які чітко узгоджені між собою та є доволі сталими у конкретної особистості. Визначено, що становлення цієї групи здібностей зумовлено процесом сочіалізації особистості, впливом як внутрішніх ресурсів і характерологічних особливостей індивіда, ґендерних відмінностей тощо, так і впливом оточуючого середовища на людину.

Автори статті вважають, що соціальний інтелект педагога вмішує когнітивний, емпатійний і мнемічний аспекти. Елементи (або скрипти, фрейми, концепти) емпатійного аспекту соціального інтелекту складають зміст конкретних усвідомлених педагогом образів реальності, які можуть бути як такими, що сприймаються безпосередньо, так і такими, що виникають у спогадах і уяві особистості. Специфічна функція емпатійного аспекту соціального інтелекту полягає в тому, що емпатійні фрейми, скрипти, концепти наділяють емоційністю продукти інтелектуальної діяльності, своєрідну картину світу, яка складається у суб'єкта в результаті роботи соціального інтелекту, внаслідок чого світ постає для суб'єкта як існуючий у метакогнітивній сорері. 
Отримані результати за рівнями сорормованості сочіального інтелекту вчителів зОШ свідчать про те, що від рівня кваліфікації вчителя, тобто від стажу роботи у школі, від віку респондента тощо рівень розвитку соціального інтелекту не залежить. Доведено, що соціальний інтелект учителя залежить, передусім, від ґендерних особливостей респондентів, а також від предметної сфери професійної діяльності, якою педагог займається з моменту закінчення закладу вищої освіти. Отже, рівень розвитку соціального інтелекту вчителя залежатиме від психологічного типу його особистості, а ией тип, у свою чергу, зумовив обрання респондентом тієї чи іншої сфери професійної діяльності (mобто, природничо-гуманітарної чи фрізико-математичної, обрання професії вчителя початкових класів тощо). Саме психологічний тип особистості вчителя великою мірою й забезпечує ампліріковану структуру здібностей педагога, які входять до його соціального інтелекту.

Ключові слова: соціальний інтелект, когнітивний аспект, емпатійний аспект, мнемічний аспект, метакогнітивна сфера, ампліфікація здібностей соціального інтелекту.

\section{Ивашкевич Эдуард, Онуфриева Лиана. Амплификация способностей социального интеллекта учителей современной средней общеобра- зовательной школы}

\section{АННОТАЦИЯ}

В статье указано, что социальный интеллект рассматривается как новообразование, в которое входят определенные особенности. Экспликация социального интеллекта является возможной только в рамках осуществления личностью субъект-субъектной деятельности. Отмечено, что амплификация способностей социального интеллекта происходит в процессе межличностного взаимодействия. Учитывая многоаспектный характер сферы экспликации способностей социального интеллекта, очевидным является то, что социальный интеллект состоит из определенного комплекса способностей, которые достаточно четко согласованы между собой, являются устойчивой амплифицированной структурой конкретной личности. Определено, что становление данной группы способностей в большой степени обусловлено процессом социализации личности, влиянием как внутренних ресурсов и характерологических особенностей индивида, гендерных различий и т. д., так и влиянием окружающей среды на человека. 
Авторы статьи считают, что социальный интеллект педагога cостоит из когнитивного, эмпатийного и мнемического аспектов. Элементы (или скрипты, фреймы, концепты) эмпатийного аспекта социального интеллекта составляют содержание конкретных осознанных педагогом образов реальности, которые могут быть такими, которые воспринимаются как непосредственно, так и такими, которые возникают в воспоминаниях и воображении личности. Специфическая функция эмпатийного аспекта социального интеллекта заключается в том, что эмпатийные фреймы, скрипты, концепты наделяют эмоциональностью продукты интеллектуальной деятельности, своеобразную картину мира, которая образовывается у субъекта в результате работы социального интеллекта, и во многом именно поэтому мир существует для субъекта исключительно в метакогнитивной сфере.

Полученные результаты по уровням сформированности социального интеллекта учителей средних школ свидетельствуют о том, что от уровня квалификации учителя, то есть от стажа работы в школе, от возраста респондента и т. д. уровень развития социального интеллекта не зависит. Доказано, что социальный интеллект учителя зависит, прежде всего, от гендерных особенностей респондентов, а также от предметной сферы профессиональной деятельности, которой педагог занимается с момента окончания учреждения высшего образования. Следовательно, уровень развития социального интеллекта учителя будет зависеть от психологического типа его личности, а этот тип, в свою очередь, детерминирует избрание респондентом той или иной сферы профессиональной деятельности (то есть, гуманитарной или физико-математической, выбор профессии учителя начальных классов и т. о.). Именно психологический тип личности учителя во многом и обеспечивает амплифицированную структуру способностей педагога, которые входят в его социальный интеллект.

Ключевые слова: социальный интеллект, когнитивный аспект, эмпатийный аспект, мнемический аспект, метакогнитивная сорера, амплификация способностей социального интеллекта. 